\title{
CLINICAL AND ANAMNESTIC FEATURES OF RESPIRATORY SYNCYTIAL VIRAL INFECTION COURSE IN INFANTS TREATED IN THE REGIONAL PEDIATRIC CLINICAL HOSPITAL
}

\section{L.V. Koliubakina, O.V.Vlasova, L.M. Stefanchuk ${ }^{1}$}

Higher State Educational Institution of Ukraine «Bukovinian State Medical University», Chernivtsi, Ukraine ${ }^{1}$ Pediatrician of CMI «Municipal pediatric polyclinic», Chernivtsi, Ukraine

Key words: newborns, respiratory syncytial virus, retrospective analysis, groups of risk.

Bukovinian Medical Herald. V.22, № 2 (86). P. 36-40.

DOI:

10.24061/2413-0737.

XXII.2.86.2018.30

\section{E-mail:}

vlasovaolena01@gmail. com
Objective: anamnestic, clinic-paraclinical findings and the course of RS-viral infection in patients, who were treated in the Neonatal Department of the RPCH of Chernivtsi are assessed.

Material and methods. A retrospective analysis of 50 case histories of children treated for RS-infection during the last year was made. During hospitalization general clinical, biochemical, instrumental methods of examination were carried out for all the children.

Results. Almost $18 \%$ of children hospitalized with RS-viral bronchiolitis received antibacterial therapy in spite of the fact that a part of accumulation of secondary bacterial infection was not higher than $8 \%$. All the children received nebulizer and symptomatic therapy. Depending on the degree of severity and clinical manifestation of the disease nebulizer therapy was performed in combination with inhalation $\beta 2$-agonists. 18 children (36\%) received inhalation glucocorticosteroids, the rest-nebulizer therapy with the use of $0,9 \% \mathrm{NaCl}$ solution. All the children in the intensive care unit required administration of oxygen supply, and one child required artificial lung ventilation. An average bed day was ten, it was longer only in three children due to preterm period.

Conclusions. The analysis of the findings showed that among patients with $R S$-viral infection, acute bronchiolitis, most children were those of the first and second month of life residing in rural districts from large families. The course of the disease tended to be favorable. The results of the study confirmed the topicality of a rational antibiotic therapy, based on the preliminary diagnosis or the data to identify the pathogenic stimulus.

\footnotetext{
Ключові слова: новонароджені, респіраторносиниитіальний вірус, ретроспективний аналіз, групи ризику.

Буковинський медичний вісник. T.22, № 2 (86). C. 36-40.
}

\section{КЛІНІЧНО-АНАМНЕСТИЧНІ ОСОБЛИВОСТІ ПЕРЕБІГУ РЕСПІРАТОРНО-СИНЦИТІАЛЬНОЇ ВІРУСНОЇ ІНФЕКЦІЇ У НОВОНАРОДЖЕНИХ, ЯКІ ПЕРЕБУВАЛИ НА СТАЦІОНАРНОМУ ЛІКУВАННІ В ОБЛАСНІЙ ДИТЯЧІЙ КЛІНІЧНІЙ ЛІКАРНІ}

Л.В. Колюбакіна, О.В. Власова, Л.М. Стефанчук

Мета роботи - провести оцінку анамнестичних, клінічно-параклінічних даних та перебігу захворювання РС-вірусної інфекиії у пацієнтів, які перебували на стаціонарному лікуванні в неонатальному блоці обласної дитячої клінічної лікарні (ОДКЛ) м. Чернівці.

Матеріал і методи. Ретроспективно проведений аналіз історій хвороб 50 дітей, які проходили лікування з приводу РС-інфекції впродовж останнього року. Під час перебування в стаціонарі всім дітям були проведені загальноклінічні, біохімічні, інструментальні методи дослідження. Результати. Майже 18\% дітей, госпіталізованих з РС-вірусним бронхіолітом, отримували антибактеріальну терапію, незважаючи на те, щуо частка нашарування вторинної бактеріальної інфекції не перевищувала 8\% випадків. Всі діти отримували небулайзерну та симп- 
томатичну терапію. Залежно від ступеня тяжккості та клінічного перебігу захворювання небулайзерна терапія проводилася у поєднанні з використанням інгаляційних $\beta 2$ - агоністів. 18 дітей (36\%) отримували інгаляційні глюкокортикостероїди, а в решти - застосовувалася небулайзерна терапія з використанням 0,9\% p-ну $\mathrm{NaCl}$. Проведення кисневої дотачії потребували всі діти під час перебування у відділенні інтенсивної терапії, а одна дитина потребувала штучної вентиляиії легень. Середній ліжкко-день склав ув середньому 10 діб, лише у трьох дітей він виявився більш тривалим у зв'язку з малим терміном гестації. Висновок. Аналіз отриманих даних показав, щэо серед хворих на РС-вірусну інфекиію, гострий бронхіоліт переважали діти першого-другого місяия життя із багатодітних сімей сільської місиевості, переважно зі сприятливим перебігом захворювання. Результати дослідження підтвердили актуальність щзодо дотримання раціональної антибактеріальної терапії, виходячи із передбаченого діагнозу або даних ідентифікаиії патогенного збудника.

\section{Ключевые слова:} новорожденные, респираторныцисинциитиальный вирус, ретроспективнылй анализ, группь риска.

Буковинский медициннский вестник. T.22, № 2 (86). C. 36-40.

\section{КЛИНИКО-АНАМНЕСТИЧЕСКИЕ ОСОБЕННОСТИ ТЕЧЕНИЯ РЕСПИРАТОРНО-СИНЦИТИАЛЬНОЙ ВИРУСНОЙ ИНФЕКЦИИ У НОВОРОЖДЕННЫХ, КОТОРЫЕ НАХОДИЛИСЬ НА СТАЦИОНАРНОМ ЛЕЧЕНИИ В ОБЛАСТНОЙ ДЕТСКОЙ КЛИНИЧЕСКОЙ БОЛЬНИЦЕ}

\section{Л.В. Колюбакина, Е.В. Власова, Л.М. Стефанчук}

Цель работы - провести оценку анамнестических, клинико-параклинических данных и течения заболевания РС-вирусной инфекиии у пациетов, которые находились на стационарном лечении в неонатальном блоке областной детской клинической больницьы (ОДКБ) г. Черновиьы.

Материал и методы. Ретроспективно проведен анализ историй болезни 50 детей, находившихся на лечении по поводу РС-инфекции в течение последнего года. Во время нахождения в стационаре всем детям проведено клинические, биохимические, инструментальные методы обследования.

Результаты. Почти 18\% детей, госпитализированных с РС-вирусным бронхиолитом, получили антибактериальную терапию, хотя наличие вторичной бактериальной инфекции наблюдалось только в 8\% случаев. Все дети получали небулайзерную и симптоматическую терапию. В зависимости от тяжести и клинического течения заболевания небулайзерная терапия проводилась с использованием ингаляционных $\beta 2$ агонистов. 18 детей (36\%) получали ингаляционные глюкокортикостероиды, а остальные - небулайзерную терапию с использованием 0,9\% p-pa NaCl. B кислородной поддержке нуждались все дети в отделении интенсивной терапии, а один ребенок был на искуственной вентиляции легких. Среднее пребывание в стационаре было 10 суток, только трое детей находились дольше в связи с маленьким гестационным возрастом. Вывод. Анализ полученных данных показал, что среди больных с РС-вирусной инфекцией, острым бронхиолитом преобладали дети первого-второго месяца жизни из многодетных семей сельской местности, преимущзественно с благоприятным течением заболевания. Результаты исследования подтвердили актуальность рационального использования антибактериальной терапии, исходя из предварительного диагноза или данных идентификации возбудителя. 
Introduction. Respiratory-syncytial (RS) virus occupies a special position among numerous respiratory viruses due to variety and severity of clinical signs of the disease, high lethal outcome among the children from risk groups [1]. Epidemic increase of sicknessa on RS-viral infection occurs annually with the peak of morbidity at the end of autumn, winter and early spring [2]. The infection is found rarely in summer. During outbreak of the disease both known serotypes of RS-virus circulate, at the same time, more severe forms of infection are associated with A serotype. The probability of RS-viral infection during the first year of life constitutes practically $50 \%$, at the same time, more severe course of the disease in the form of bronchiolitis, obstructive bronchitis and pneumonia is found among the children from risk groups, in particular: preterm infants, especially those under 3 months and with the body weight less than $5 \mathrm{~kg}$ on the moment of infection, children who were on artificial lung ventilation or prolonged oxygen supply with further formation of bronchial-pulmonary dysplasia, patients with cystic fibrosis, nervous-muscular diseases and immune deficiency conditions, hemodynamically significant congenital heart defects. The risk group also includes male sex, low body weight at birth, passive smoking, crowding and unsatisfactory material-living conditions [1, 3, 4]. RS-viral infection is able to cause the outbreak of nosocomial infection depending on the period of hospitalization which is provoked by the ability to transmit the virus not only by means of airborne way but also by means of the contact-everyday route through clothes, hands of the staff, things used for care.

Mortality rate due to RS-viral infection among healthy infants ranges within $0,3-1 \%$ cases, but it is 1 - times as much among the children with congenital heart defects and practically 20 times as much in preterm infants born in the term of gestation less than 32 weeks, and 35 times as much in patients with bronchial-pulmonary dysplasia [5]. Approximately $10 \%$ of patients with RS-viral infection require urgent medical aid and hospitalization, especially those from risk groups $[1,6]$.

The issue concerning the role of RS-viral infection in the development of hyperactivity of the bronchi and possible risk factor in the formation of brocnhial asthma remains topical nowadays. The issue concerning treatment of acute viral bronchiolitis is no less topical, as therapeutic approaches to it differ in different medical establishments in spite of the existing regulatory base available.

In recent times the emphasis has moved to the side of prevention of RS-viral bronchiolitis [7].

On the assumption of the above the objective of the study was assessment of anamnestic, clinical-paraclinical findings and the course of the disease caused by RS-viral infection in patients treated in the Neonatal Department of the Regional Pediatric Clinical Hospital, Chernivtsi.

Material and methods. A retrospective analysis of 50 case histories of children treated on RS-infection during the last year was made.
During hospitalization general clinical, biochemical, instrumental methods of examination were carried out for all the children.

Results and their discussion. The patients aged from 1 to 2 months of life (50\%) prevailed among children treated. A part of infants under 1 month was $40 \%$, and the rest $10 \%$ - the patients older than 2 months. According to the term of gestation a part of preterm infants was $14 \%$, and term ones - $86 \%$ of cases. Every third child was born to a large family with pre-school and school children. Boys constituted $56 \%$, and rural inhabitants - $78 \%$ of cases.

According to the time of hospitalization since the moment of the onset of the disease practically $66 \%$ of patients were admitted in the first three days, 38\% of them were treated at the pre-admission stage, including $8 \%$ of patients with initiated antibacterial therapy. The analysis of anamnesis admitted that every fifth child was admitted in severe condition requiring intensive care in $20 \%$ of cases. The prevailing complaints during admission included unproductive cough, running nose, neurological symptoms in the form of changed behavior, lowered appetite and sucking activity. Only every third child was running low grade fever. Respiratory disorders in the form of mixed shortness of breath were registered in $40 \%$ of cases, cyanosis - in $8(18 \%)$ of children, and two patients on admission were suffering from pathologic apnea.

Under conditions of limited possibilities the diagnosis of RS-viral infection, bronchiolitis was made mainly by clinical findings and the course of the disease.

Objective examination of children in the Department found the following respiratory disorders: inflation of the chest, dyspnea of inspiration character mainly and auscultative changes in the lungs in the form of fine-bubbling diffuse moist rales, constituting practically $80 \%$ of cases. Thoracic retraction was found in almost half of the children.

The signs of hemodynamic instability were registered in $8 \%$ of patients. One child with artificial lung ventilation and prolonged oxygen supply in the anamnesis due to the development of respiratory distress-syndrome after discharge from the hospital was hospitalized again on the 5 th days since the onset of the disease with the signs of multiple organ failure resulting in unfavourable course of the disease.

Almost $18 \%$ of children hospitalized with RS-viral bronchiolitis received antibacterial therapy in spite of the fact that a part of accumulation of secondary bacterial infection was not higher than $8 \%$. The analysis of literature data is indicative of the fact that antibacterial therapy was indicated for $34-98 \%$ of children with bronchiolitis even without evidenced efficacy [8]. All the children received nebulizer and symptomatic therapy. Depending on the degree of severity and clinical manifestation of the disease nebulizer therapy was performed in combination with inhalation $\beta 2$-agonists. 18 children (36\%) received inhalation glucocorticosteroids, the rest - nebulizer 
therapy with the use of $0,9 \% \mathrm{NaCl}$ solution. Although there are no evidences concerning the efficacy of administration of glucocorticosteroids in case of bronchiolitis [9], parenteral glucocorticosteroids with a short course were indicated for half of the children. All the children in the intensive care unit required administration of oxygen supply, and one child required artificial lung ventilation. An average bed day was ten, it was longer only in three children due to preterm period.

Conclusions. The analysis of the findings obtained demonstrated that among patients with RS-viral infection, acute bronchiolitis, children of the first-second month of life from large families in the rural areas prevailed with a favourable course of the disease. The results of the study evidenced the topicality concerning initiation of rational antibacterial therapy on the basis of the predicted diagnosis or the data to identify a pathogenic agent.

\section{Список літератури}

1. Бабаченко ИВ. и др. Клинико-эпидемиологические особенности респираторно-синцитиальной инфекции у детей раннего возраста. Актуальные вопросы инфекционной патологии и вакцинопрофилактики у детей. Материалы VIII Конгресса детских инфекционистов России, 2009 Дек 16-18, Москва. Москва; 2009.8.

2. Кожевникова ЕН, Горелов АВ. Клинико-эпидемиологические особенности и лечение РС-вирусной инфекции у детей. Инфекционные болезни. 2007; 5(4):15-21.

3. Знаменская ТК, Жданович АИ, Коломийченко.В. Респираторно-синцитиальная вирусная инфекция у новорожденных. Неонатологія, хірургія та перинатальна медицина. 2012; 2,(1):186-91.

4. Куличенко ТВ. Респираторная синцитиальная вирусная инфекция у детей: новые исследования. Неонатологія, хірургія та перинатальна медицина. 2012; 2, (1):133-40.

5. Овсянников Д Ю. Бронхолегочная дисплазия - фактор риска тяжелого течения респираторно-синцитиальной вирусной инфекции у детей. Педиатрическая фармакология. 2009; 6,(4):88-99.

6. Сергиенко ЕН. Современный взгляд на респираторно-синцитиальную вирусную инфекцию у детей. Медицинский журнал. 2013; 1:18-22.

7. Шунько ЄС, Лакша ОТ, Жовнір ВА. Інформаційний лист про нововведення в системі охорони здоров'я: Профілактика респіраторно-синцитіальної вірусної інфекції у дітей груп високого ризику [Newsletter on innovation in health care: prevention syntytsialnoyi respiratory viral infections in children at high risk] № 291. 2011.
8. Spurling GK, Fonseka K, Doust J, et al. Antibiotics for bronchiolitis in children. Cochrane Database Syst Rev. 2007: CD005189. doi:10.1002/14651858.CD005189.pub2

9. Walsh $\mathrm{P}$, et al. Comparison of nebulised epinephrine to albuterol in bronchiolitis. Acad. Emerg. Med.2008; 15:30513. doi: $10.1111 / \mathrm{j} .1553-2712.2008 .00064 . x$.

\section{References}

1. Babachenko IV i dr. Kliniko-jepidemiologicheskie osobennosti respiratorno-sincitial'noj infekcii u detej rannego vozrasta. Aktual'nye voprosy infekcionnoj patologii i vakcinoprofilaktiki u detej [Clinico-epidemiological features of respiratory syncytial infection in young children. Topical issues of infectious pathology and vaccine prevention in children]. Materialy VIII Kongressa detskih infekcionistov Rossii, 2009 Dek 16-18 Moskva, Moskva; 2009.8. (in Russian).

2. Kozhevnikova EN, Gorelov AV. Kliniko-jepidemiologicheskie osobennosti i lechenie RS-virusnoj infekcii u detej [Clinical and epidemiological features and treatment of RS-viral infection in children]. Infekcionnye bolezni. 2007; 5(4):15-21. (in Russian).

3. Znamenskaia TK, Zhdanovych AY, Kolomyichenko TV. Respiratorno-sincitial'naja virusnaja infekcija u novorozhdennyh [Respiratory syncytial viral infection in newborns]. Neonatolohiia, khirurhiia ta perynatal'na medytsyna. 2012; 2,(1):186-91. (in Ukrainian)

4. Kulychenko TV. Respiratornaja sincitial'naja virusnaja infekcija u detej: novye issledovanija [Respiratory syncytial viral infection in children: new research]. Neonatolohiia, khirurhiia ta perynatal'na medytsyna. 2012; 2, (1):133-140. (in Ukrainian)

5. Ovsjannikov D Ju. Bronholegochnaja displazija — faktor riska tjazhelogo techenija respiratorno-sincitial'noj virusnoj infekcii u detej [Bronchopulmonary dysplasia is a risk factor for severe course of respiratory syncytial viral infection in children]. Pediatricheskaja farmakologija. 2009; 6,(4):88-99. (in Russian).

6. Sergienko EN. Sovremennyj vzgljad na respiratorno-sincitial'nuju virusnuju infekciju u detej [Modern view of respiratory syncytial viral infection in children]. Medicinskij zhurnal. 2013; 1:18-22. (in Russian).

7. Shun'ko Ie Ie, Laksha OT, Zhovnir VA. Informatsiinyi lyst pro novovvedennia v systemi okhorony zdorov'ia: Profilaktyka respiratorno-syncitial'noi virusnoi infektsii u ditei hrup vysokoho ryzyku № 291. 2011.(in Ukrainian)

8. Spurling GK, Fonseka K, Doust J, et al. Antibiotics for bronchiolitis in children. Cochrane Database Syst Rev. 2007: CD005189. doi:10.1002/14651858.CD005189.pub2

9. Walsh P, et al. Comparison of nebulised epinephrine to albuterol in bronchiolitis. Acad. Emerg. Med. 2008; 15:305-13. doi:10.1111/j.1553-2712.2008.00064.x.

\section{Відомості про авторів:}

Колюбакіна Лариса Вікторівна — кандидат медичних наук, доцент кафедри педіатрії та дитячих інфекційних хвороб Вищого державного навчального закладу України «Буковинський державний медичний університет», м. Чернівці, Україна.

Власова Олена Василівна - кандидат медичних наук, докторант кафедри педіатрії та дитячих інфекційних хвороб Вищого державного навчального закладу України «Буковинський державний медичний університет» м. Чернівці, Україна.

Стефанчук Лілія Михайлівна — лікар-педіатр КМУ «Міська дитяча поліклініка», м. Чернівці, Україна.

\section{Сведения об авторах:}

Колюбакина Лариса Викторовна - кандидат медицинских наук, доцент кафедры педиатрии и детских инфекционных заболеваний Высшего государственного учебного заведения Украины «Буковинский государственный медицинский университет», г. Черновцы, Украина.

Власова Елена Васильевна - кандидат медицинских наук, докторант кафедры педиатрии и детских инфекционных заболеваний Высшего государственного учебного заведения Украины «Буковинский государственный медицинский 
университет», г. Черновцы, Украина. Эл. почта: vlasovaolena01@gmail.com

Стефанчук Лилия Михайловна - врач-педиатр КМУ «Городская детская поликлиника», г. Черновцы, Украина. Information about the authors:

Koliubakina Larysa Viktorivna - candidate of Medical Sciences, Associate Professor, Department of Pediatrics and Children Infectious Diseases, Higher State Educational Institution of Ukraine «Bukovinian State Medical Universit»”, Chernivtsi, Ukraine.

Vlasova Olena Vasylivna — candidate of Medical Sciences, Department of Pediatrics and Children Infectious Diseases, Higher State Educational Institution of Ukraine «Bukovinian State Medical University», Chernivtsi, Ukraine. E-mail: vlasovaolena01@gmail.com

Stefanchuk Liliya Mykhaylivna — Pediatrician, Municipal Medical Establishment «Municipal Pediatric Polyclinic», Chernivtsi, Ukraine. 